\title{
Effect of water availability and seed source on physical dormancy break of Vicia villosa ssp. villosa
}

\author{
Juan P. Renzi ${ }^{1,2 \star}$, Guillermo R. Chantre ${ }^{2,3}$ and Miguel A. Cantamutto ${ }^{1,2,3}$ \\ ${ }^{1}$ Instituto Nacional de Tecnología Agropecuaria, 8142 Hilario Ascasubi, Argentina; ${ }^{2}$ Departamento de Agronomía, \\ Universidad Nacional del Sur, San Andrés 800, Altos de Palihue, 8000 Bahía Blanca, Argentina; ${ }^{3}$ Centro de \\ Recursos Naturales Renovables de la Zona Semiárida (CERZOS-CONICET), 8000 Bahía Blanca, Argentina
}

(Received 29 September 2015; accepted after revision 9 May 2016; first published online 14 June 2016)

\begin{abstract}
Physical dormancy (PY) plays a crucial role in the control of the reseeding process of Vicia villosa Roth, a winter annual species cultivated for pasture and hay, naturalized in several semi-arid temperate agroecosystems. As PY is considered a seed trait modulated by natural selection, populations from different origins are expected to show different responses to environmental regulatory factors. The present study aimed to determine the effect of: (1) water availability on PY-break dynamics of a naturalized population from Argentina (ASC) under both laboratory and field conditions; (2) the seed source on initial PY and dormancy release rate (wet storage at $20^{\circ} \mathrm{C}$ ) of ASC compared to 45 other populations of $V$. villosa, including wild, naturalized, landraces and cultivars. Water availability increased PY loss rate under both storage and field conditions. ASC PY-break dynamics was adequately described by a Gompertz model with a lower thermal-time requirement estimated for dormancy break under fluctuating soil water conditions compared to seeds buried inside impermeable bags. During the field burial experiment, a considerable proportion of seeds ( $70 \%$ ) became water permeable during the summer season after dispersal, and retained low levels of residual PY for soil seed bank replenishment. Improved populations (i.e. breeding cultivars) showed the lowest percentages of initial PY compared to landraces, naturalized and wild populations. Naturalized populations of Argentina showed similar initial PY compared to landraces, although PY release rate was lower in the former and might be attributed to local environmental selection. Wild types showed the lowest PY release rates.
\end{abstract}

Keywords: physical dormancy, semi-arid environment, thermal-time, Vicia villosa genotypes, winter annual

\footnotetext{
*Correspondence

Email: renzipugni.juan@inta.gob.ar
}

\section{Introduction}

Physical dormancy (PY) is imposed by both physical and chemical impediments to water movement across the seed coat, caused by the presence of phenolic compounds and suberin layers impregnating the palisade cells (Baskin et al., 2000). PY is considered one of the main traits responsible for the control of germination of several angiosperms, including the largest, and agronomically valuable, legume family Fabaceae (de Souza et al., 2012). Barriers to water movement across the seed are acquired during the end of the seed ripening phase on the mother plant (Hyde, 1954; Rolston, 1978; Kucewicz et al., 2010; Gama-Arachchige et al., 2011). Under natural conditions, such seeds, usually termed 'hard seeds', remain under PY until the seed coat turns permeable by the action of environmental factors (Hu et al., 2009). The specific site of water entry through the seed coat is still a matter of debate. Some legume species have developed specialized structures such as strophioles or lenses. The morphological characteristics of these 'water gaps' can vary between species (Gama-Arachchige et al., 2013), but are usually associated with natural openings of the seed, maintained up to the end of the seed development phase (i.e. hilum, micropyle or chalaza) (Smýkal et al., 2014).

A number of mechanisms have been proposed for PY break under field conditions, including high and diurnally fluctuating temperatures, relatively short periods of extreme dry heat (e.g. fire exposure) or alternating soil wetting/drying cycles (Hu et al., 2009; Santana et al., 2010). However, it is not yet well understood how germination is regulated in ecosystems with a temperate climate, where fire occurs very rarely and daily soil temperature fluctuations are rather limited (Van Assche et al., 2003). Seeds with PY might overcome their dormant status after mechanical abrasion by soil particles, microbiological decomposition of the seed coat, or seed coat degradation caused by partial or complete consumption by herbivores. However, 
published evidence for these alternative mechanisms of scarification is scarce (Baskin and Baskin, 2014).

Vicia villosa is a cosmopolitan, non-native invader present in several temperate regions of America, where it was introduced intentionally as a forage crop (Gunn, 1979; Aarssen et al., 1986). The inclusion of $V$. villosa in agricultural rotations has a crucial economic value in semi-arid ecosystems, where the relatively high cost of nitrogen $(\mathrm{N})$ chemical fertilization affects grain crop yield and quality substantially (Ates et al., 2013; Renzi and Cantamutto, 2013). The biological $\mathrm{N}$ fixation ability of $V$. villosa as well as its natural reseeding potential are valuable agronomic traits that could contribute to agroecosystem sustainability in semi-arid regions (Renzi and Cantamutto, 2013).

V. villosa has been known to expand from cultivated areas to form spontaneous populations, such as in winter cereals, orchards, pastures and forestry fields (Aarssen et al., 1986). It is also found as a ruderal species along roadsides, disturbed areas and fallow fields. Under natural conditions, a healthy stand could generate over 1000 seeds $\mathrm{m}^{-2}$. However, the dispersal potential of $V$. villosa is very limited due its large seed size (length $\approx 4.2 \mathrm{~mm}$, weight $\approx 35 \mathrm{mg} \mathrm{seed}^{-1}$ ) and absence of effective dispersal mechanisms (Jannink et al., 1997; Renzi and Cantamutto, 2013).

Seed dormancy of $V$. villosa is controlled by a combination of physical impediments for water movement across the seed coat (PY) and a physiological component of dormancy (PD) (Renzi et al., 2014). Embryos overcome PD and become non-PD after a short afterripening period. Thus, PY could be considered the main component of seed dormancy of $V$. villosa. The combination of a hard seed coat and a dormant embryo is considered as a 'double-safety' mechanism to prevent early germination during summer when soil water content and temperature are not adequate for seedling survival (Van Assche and Vandelook, 2010; Gama-Arachchige et al., 2013). Under natural conditions, $V$. villosa pods shatter and disperse the seeds during early summer, fulfilling their thermal-time requirements for PY break by the end of the season. Emergence flushes occur in the following autumn when soil temperature and moisture become favourable for seedling recruitment.

Under laboratory test rules (ISTA, 2011), a prechilling procedure is recommended to improve germination of species with PY dormancy, such as Lotus, Medicago, Lupinus, Melilotus, Trifolium and Vicia. However, this procedure is not of general applicability. Within each genus, species may have different responses caused by adaptive ecological traits (Grime et al., 1981; Van Assche et al., 2003; Hu et al., 2013). Seed stratification after seed maturity is cited as a successful PY-break treatment for $V$. grandiflora Scop., $V$. cracca L., V. hirsuta L. (Gray), V. bythinica L. and $V$. ervilia L. Willd. (Elkins et al., 1966; Van Assche et al., 2003; Samarah et al., 2003, 2004; Kucewicz et al., 2010; Basaran et al., 2012; Uzun et al., 2013). Conversely, PY break of $V$. villosa generally occurs by exposure to high temperatures (i.e. afterripening) (Jones, 1928; Renzi et al., 2014). Interspecific variability in response might be a result of life form (perennial, winter or summer annual) or adaptation to a local environment (Grime et al., 1981; Hu et al., 2009).

Temperature and water availability are the main environmental factors regulating PY break (Baskin et al., 2000). High moisture availability could be an important environmental cue to promote water permeability of some PY seeds. However, the effect of moisture availability as a dormancy breaking factor has not received much attention (Baskin and Baskin, 2014). In the semi-arid temperate area of Argentina, precipitation regimes are erratic. Thus, inter- and intra-annual variability of soil water content might be an important factor regulating the soil seed bank dynamics of $V$. villosa populations.

The mechanism and environmental factors associated with PY break under natural conditions are poorly understood ( $\mathrm{Hu}$ et al., 2009). It is unknown what the potential relevance of this seed trait is for wild, naturalized or improved populations. As PY could be considered a trait developed under natural selection, populations from different origins should show different responses to environmental regulatory factors. To address this knowledge gap, the present study aimed to determine the effect of: (1) water availability on PY-break dynamics of a naturalized population from Argentina (ASC) under both laboratory and field conditions; (2) the seed source on initial PY and dormancy release rate of ASC compared to 45 other populations of $V$. villosa, including wild, naturalized, landraces and cultivars.

\section{Materials and methods}

\section{Hilario Ascasubi population (ASC) seed collection}

A naturalized population of $V$. villosa from the EEA Hilario Ascasubi (Buenos Aires, Argentina) was selected as the seed source during three growing seasons (December 2008, 2009 and 2011). ASC was located in a sandy loam soil $(\mathrm{pH}=7.5$, soil organic matter $=$ $1.2 \%$, available $\mathrm{P}$ Bray \& Kurtz $=24 \mathrm{mg} \mathrm{kg}^{-1}$ ) along an internal road margin of a plot cultivated with winter cereals [wheat (Triticum aestivum) and rye (Secale cereale)]. The predominant climate in this habitat is semi-arid temperate with $489 \mathrm{~mm}$ mean annual precipitation and $14.8^{\circ} \mathrm{C}$ mean annual temperature (EEA H. Ascasubi, 1966-2014; http://inta.gob.ar/documentos/informes-meteorologicos). 


\section{Post-harvest PY breaking (only for ASC)}

\section{Dry and wet storage}

Batches of 50 seeds $(n=3)$ were dry-stored (inside paper bags) at $20 \pm 2^{\circ} \mathrm{C}$. The proportion of PY seeds was assessed (see the description of the imbibition test in the Data analysis section, below) after 0, 15, 70, 105, 182 and $295 \mathrm{~d}$ of storage (DOS) in 2010. For wet conditions, batches of 100 seeds $(n=3)$ were incubated at the same temperature in 9-cm-diameter Petri dishes over two layers of filter paper saturated with distilled water. The time course for PY break under wet storage was registered during 2010 and it was compared with dry storage for the same period. Imbibed seeds (i.e. non-PY seeds) were counted after 15, 70, 105, 182 and 295 DOS.

\section{Field burial inside permeable and impermeable bags}

During 2009/10, 2010 and 2012/15 periods, at the onset of the summer season after natural seed dispersal (i.e. January 2009, 2010 and 2012), batches of 100 seeds were placed inside permeable nylon mesh bags $(10 \times$ $10 \mathrm{~cm}$ ) in order to create natural soil conditions (diffusion of air and water, micro-organisms, etc.) and were buried in the field at depth $5 \mathrm{~cm}$ in a bare-soil site (without vegetation or litter). The burial site was near the natural habitat of ASC $(<100 \mathrm{~m})$. Seeds were exhumed after $0,30,78,122,157,184,333$ and 421 days of burial (DOB) in 2009/10; after 0, 40, 60, 140 and 230 DOB during 2010; and after 84, 174, 272, 357, 453, 459, 543, 628, 719 and 747 DOB during 2012/15. During 2010, a set of seeds was buried inside impermeable nylon bags (102 microns) and further exhumed at the same time intervals. A completely randomized factorial design was used during 2009/10 $(n=6)$ and $2012 / 15(n=3)$ periods. Field temperature was recorded at seed burial depth every $2 \mathrm{~h}$ using digital temperature data loggers (Thermochron Ibuttons, Model DS1921G-F50; Maxim Integrated Products, Inc., San Jose, California, USA). Data obtained from permeable bags were used to develop a thermal-time model.

\section{Thermal-time requirements for PY break under field conditions}

In order to quantify the effect of the afterripening time and temperature on $V$. villosa physical dormancy break process under natural soil conditions (i.e. permeable bags), an afterripening thermal-time index $\left(\theta_{A T P Y}\right)$ was implemented. The accumulation of afterripening thermal-time was calculated according to Renzi et al. (2014):

$$
\theta_{A T P Y}=\sum_{i=1, n} \theta_{n}
$$

where

$$
\theta_{n}= \begin{cases}T_{i}-T_{b} & \text { if } T_{b}<T_{i} \\ 0 & \text { otherwise }\end{cases}
$$

$\theta_{A T P Y}$ is the afterripening thermal-time at day $n, T_{i}$ is the estimated mean daily soil temperature during the afterripening time period, and $T_{b}$ is the base temperature, estimated as $9.8^{\circ} \mathrm{C}$ (Renzi et al., 2014) below which afterripening does not occur.

The fraction of non-PY seeds (i.e. population fraction without PY) was plotted as a function of burial time and temperature. A thermal-time model for PY break was developed by fitting a non-linear function to relate the proportion of non-PY seeds as a function of thermal-time accumulation $\left(\theta_{A T P Y}\right)$. A non-linear fitting routine was performed using the LevenbergMarquardt algorithm with GraphPad Prism Software version 6.0 (GraphPad, San Diego, California, USA).

\section{Seed collection sources}

In order to determine the representativeness of the ASC seed collection, it was contrasted with other seed sources, including 45 spontaneous and cultivated accessions from Argentina and Europe. Germplasm from Argentina consisted of 17 naturalized populations collected during December 2013 from a representative plant sample $(n>30)$. A sample of Argentinian landraces $(n=11)$ maintained by farmers was also included (Fig. 1). Wild and cultivated germplasm of $V$. villosa from Europe was represented by 18 populations. Matured seeds of three wild populations of $V$. villosa were collected by J.P.R. in August 2013 from plants growing in natural habitats of Serbia, in Radenka II $\left(21^{\circ} 46^{\prime} \mathrm{E}, 44^{\circ} 34^{\prime} \mathrm{N}\right)$, Petrovo Selo $\left(22^{\circ} 24^{\prime} \mathrm{E}\right.$, $\left.44^{\circ} 38^{\prime} \mathrm{N}\right)$ and Senokos $\left(22^{\circ} 54^{\prime} \mathrm{E}, 43^{\circ} 08^{\prime} \mathrm{N}\right)$. The country of origin and accession number of each cultivar, provided by the Research Institute of Crop Production (CRI) of the Czech Republic, are shown in Table 1 (for more information see http://genbank.vurv.cz/ genetic/resources/).

Geographic altitude and climatic conditions of collected populations from Argentina and Europe are detailed in Table 2. The mean temperature of the hottest and coolest months and the average annual rainfall during growing seasons (nearest locality) were obtained from de Fina (1992) and www.worldclimate.com. The growing season for $V$. villosa was defined as from March to November for Argentinian populations and from November to July for wild populations from Serbia.

\section{Seed production for comparative PY experiments}

Seeds from each population source (Tables 1 and 2) were cultivated at the Experimental Agricultural 


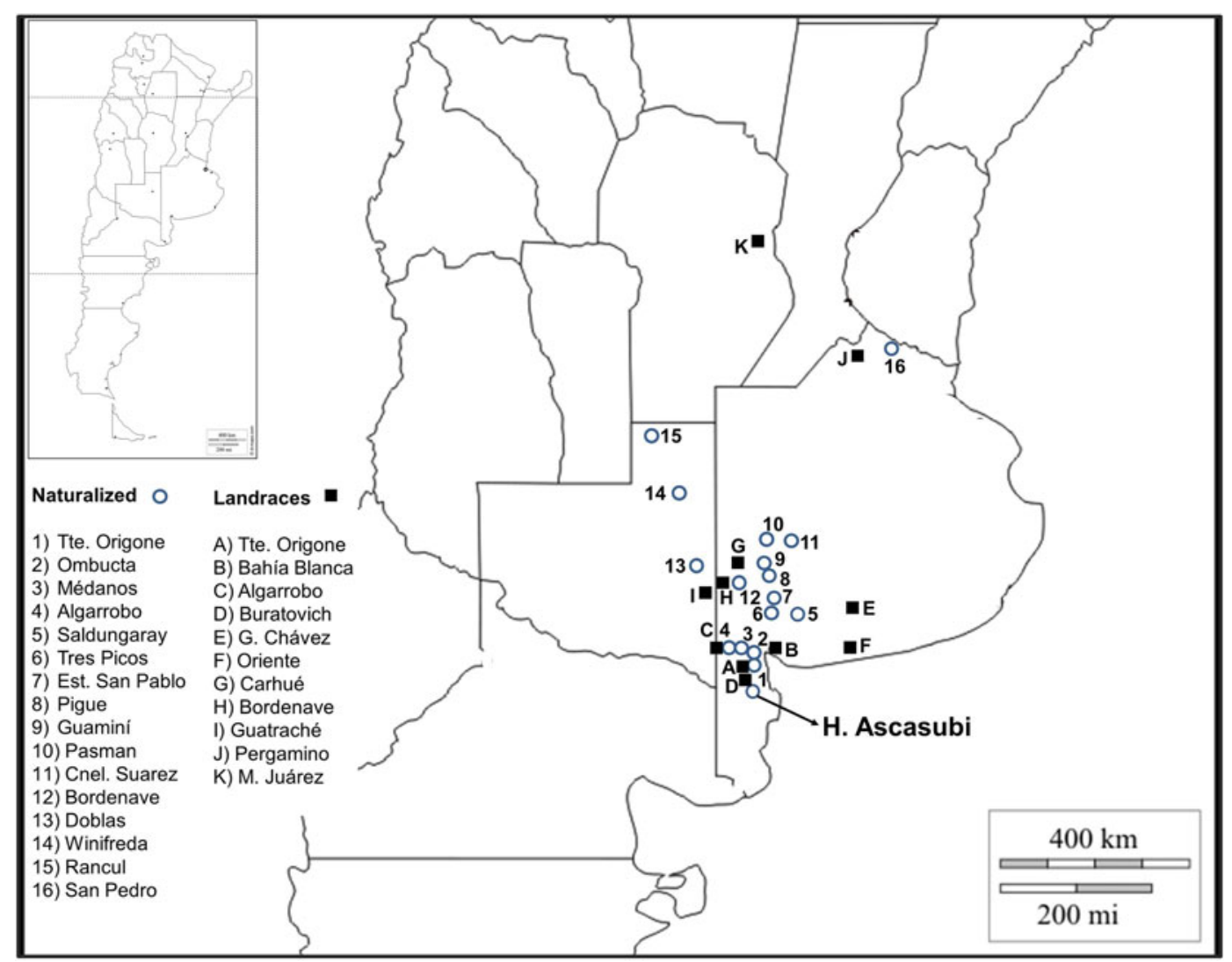

Figure 1. Seed collection sites of naturalized (circles) and landrace (squares) Vicia villosa populations from Argentina.

Station (EEA) of Hilario Ascasubi $\left(62^{\circ} 37^{\prime} \mathrm{W}, 39^{\circ} 23^{\prime} \mathrm{S}\right)$, located in the south of the semi-arid temperate region of Argentina, during the 2014 growing season. The soil of the experimental site was an entic haplustoll, sandy loam, slightly alkaline $(\mathrm{pH} 7.6)$, high in phosphorus (P) content (19.4 ppm P Bray \& Kurtz) and low organic matter content (1.84\%). A common garden was established in an experimental plot $\left(2 \mathrm{~m}^{2}\right)$ which was sown on 10 April 2014, and consisted of $\approx 40$ plants per accession $(n=3)$. Seeds from mature pods (brown colour) were harvested manually on 18 December 2014.

Table 1. Passport information of the investigated European cultivar accessions

\begin{tabular}{|c|c|c|c|}
\hline \multirow[t]{2}{*}{ Country of origin } & \multicolumn{2}{|c|}{ Accession } & \multirow[t]{2}{*}{ Year of inclusion into collection* } \\
\hline & Number & Name & \\
\hline Hungary & 05L1700047 & Simabuekkoeny & 1967 \\
\hline Yugoslavia & 05L1700036 & Sarajevo & 1966 \\
\hline Poland & 05L1700015 & Sielecka & 1961 \\
\hline Australia & 05L1700046 & 61781 & 1966 \\
\hline Bulgaria & 05L1700059 & 26699 & 1969 \\
\hline \multirow[t]{2}{*}{ Czechoslovakia } & 05L1700075 & Modra & 1987 \\
\hline & 05L1700071 & Viola & 1981 \\
\hline \multirow[t]{2}{*}{ German Democratic Republic } & 05L1700066 & Oregon & 1974 \\
\hline & 05L1700032 & Welta & 1964 \\
\hline Germany & 05L1700062 & Polyp & 1973 \\
\hline \multirow[t]{2}{*}{ Poland } & 05L1700067 & Rea & 1976 \\
\hline & 05L1700068 & Rod MPI & 1976 \\
\hline \multirow[t]{3}{*}{ Union of Soviet Socialist Republics } & 05L1700070 & Pridesnjanskaja & 1973 \\
\hline & 05L1700061 & Stavcanka & 1970 \\
\hline & 05L1700054 & Stenskaja 24 & 1969 \\
\hline
\end{tabular}

*EVIGEZ: Plant Genetic Resources Documentation of the Czech Republic. 
Table 2. Macro-environmental conditions of the naturalized, landrace and wild populations of Vicia villosa

\begin{tabular}{|c|c|c|c|c|c|c|}
\hline \multirow[b]{2}{*}{ Locality } & \multirow[b]{2}{*}{ Status } & \multirow{2}{*}{$\begin{array}{l}\text { Altitude } \\
\text { (m asl) }\end{array}$} & \multicolumn{2}{|c|}{ Mean temperature $\left({ }^{\circ} \mathrm{C}\right)$} & \multicolumn{2}{|c|}{ Rainfall (mm) } \\
\hline & & & Hottest month & Coldest month & Year & Growing season \\
\hline H. Ascasubi (ASC) & Naturalized & 16 & 22.6 & 7.2 & 443 & 308 \\
\hline Saldungaray & & 213 & 20.7 & 6.4 & 643 & 463 \\
\hline Bordenave & & 217 & 22.6 & 6.5 & 603 & 424 \\
\hline Doblas & & 150 & 24.1 & 7.2 & 542 & 366 \\
\hline Winifreda & & 163 & 24.5 & 7.7 & 535 & 351 \\
\hline Rancul & & 246 & 24.9 & 8.1 & 664 & 395 \\
\hline San Pedro & & 36 & 23.4 & 9.8 & 960 & 689 \\
\hline Tte. Origone & & 14 & 22.5 & 7.2 & 466 & 335 \\
\hline Ombucta & & 19 & 22.5 & 7.2 & 476 & 347 \\
\hline Tres Picos & & 243 & 21.0 & 6.1 & 587 & 424 \\
\hline Est. San Pablo & & 357 & 21.0 & 6.1 & 615 & 442 \\
\hline Pigue & & 274 & 21.5 & 6.1 & 680 & 471 \\
\hline Guamini & & 116 & 23.8 & 7.3 & 674 & 475 \\
\hline Pasman & & 165 & 22.6 & 6.8 & 699 & 485 \\
\hline Cnel. Suárez & & 225 & 21.5 & 6.3 & 697 & 482 \\
\hline Médanos & & 42 & 22.9 & 7.2 & 474 & 348 \\
\hline Algarrobo & & 47 & 23.3 & 7.1 & 454 & 326 \\
\hline Bahia Blanca & Landraces & 22 & 23.4 & 7.6 & 585 & 404 \\
\hline Pergamino & & 71 & 23.3 & 9.2 & 944 & 640 \\
\hline Guatrache & & 136 & 23.5 & 6.7 & 580 & 379 \\
\hline M. Juárez & & 144 & 23.7 & 9.0 & 841 & 534 \\
\hline Bordenave & & 217 & 22.6 & 6.5 & 603 & 424 \\
\hline Carhue & & 120 & 23.8 & 7.2 & 632 & 419 \\
\hline Oriente & & 33 & 20.2 & 7.8 & 700 & 532 \\
\hline Buratovich & & 12 & 22.5 & 7.2 & 453 & 319 \\
\hline Tte. Origone & & 14 & 22.5 & 7.2 & 466 & 335 \\
\hline G. Chavez & & 205 & 20.7 & 7.0 & 717 & 505 \\
\hline Algarrobo & & 47 & 23.3 & 7.1 & 454 & 326 \\
\hline Radenka II. & Wild & 490 & 21.0 & 0.0 & 621 & 496 \\
\hline Petrovo Selo & & 484 & 21.5 & -0.5 & 731 & 584 \\
\hline Senokos & & 781 & 19.0 & -0.5 & 863 & 662 \\
\hline
\end{tabular}

\section{Data analysis}

After harvesting from the common garden, seeds were cleaned, and seed biomass and moisture content were estimated. Seed biomass was determined for a sample of 100 individuals (Table 3). Moisture content was determined by weighing a batch of 100 seeds, which were then oven-dried at $105^{\circ} \mathrm{C}$ for $24 \mathrm{~h}$ before being weighed again.

PY seeds (i.e. 'hard' or impermeable) were determined by an imbibition test performed at $20 \pm 2^{\circ} \mathrm{C}$ for $3 \mathrm{~d}$ (Baskin and Baskin, 2014). Intact and ungerminated seeds of each replicate were placed on moist filter paper in Petri dishes and watered daily with tap water. Imbibed seeds showed a visible change in their size/volume ratio, and were easily distinguished from unimbibed ones. The seed coat colour was always lighter for imbibed seeds than for unimbibed ones (Jones, 1928).
Seed viability was assessed for ungerminated seeds by slicing them longitudinally and immersing them in a $0.5 \%$ tetrazolium chloride (2,3,5-triphenyltetrazolium chloride) solution for $24 \mathrm{~h}$ at $30^{\circ} \mathrm{C}$ in the dark (ISTA, 2011). Seeds with pink or red stained embryos were considered viable. The total number of viable seeds consisted of germinated + stained.

For all populations, cumulative percentages of PY break (i.e. non-PY seeds $=$ germinated + imbibed seeds) were analysed by linear regression. Initial PY (\%) (19 December 2014) and PY-break dynamics as a function of storage time $(38 \mathrm{~d})$ and temperature $\left(20^{\circ} \mathrm{C}\right)$ under wet conditions were analysed by analysis of variance (ANOVA) (LSD test) and linear regression analysis using GraphPad Prism Software version 6.0 (GraphPad). Differences were considered significant at $P$ value $<0.05$ when compared to ASC. Accessions were grouped by status and were compared by 
Table 3. Seed weight and initial PY (mean and standard deviation), PY-release rate (wet-20 $\mathrm{C}$ for $38 \mathrm{~d}$ ) and viability of Vicia villosa accessions compared to ASC (H. Ascasubi population), and mean for each status

\begin{tabular}{|c|c|c|c|c|c|c|c|c|}
\hline \multirow{2}{*}{\multicolumn{2}{|c|}{ Accessions of $V$. villosa }} & \multirow{3}{*}{$\begin{array}{c}\text { Seed weight } \\
(\mathrm{mg})\end{array}$} & \multicolumn{5}{|c|}{ Physical dormancy } & \multirow{3}{*}{$\begin{array}{c}\text { Seed viability } \\
(\%)\end{array}$} \\
\hline & & & \multicolumn{3}{|c|}{ Initial } & \multicolumn{2}{|c|}{ Release } & \\
\hline Locality/Acc. number & Status & & $(\%)$ & SD & $P$ value ${ }^{2}$ & slope $(a)^{1}$ & $P$ value ${ }^{2}$ & \\
\hline H. Ascasubi (ASC) & Naturalized & 27.6 & 80.0 & 6.9 & - & -0.68 & - & 99 \\
\hline Doblas & & 30.4 & 84.0 & 6.9 & ns & -1.21 & ns & 100 \\
\hline Winifreda & & 26.4 & 86.7 & 8.3 & ns & -0.99 & ns & 97 \\
\hline Rancul & & 31.5 & 83.3 & 0.0 & ns & -0.78 & ns & 100 \\
\hline San Pedro & & 22.8 & 70.7 & 8.3 & ns & -1.13 & $* *$ & 99 \\
\hline Tte. Origone & & 32.3 & 88.0 & 0.0 & ns & -0.54 & ns & 100 \\
\hline Ombucta & & 27.1 & 77.3 & 2.3 & ns & -0.75 & ns & 100 \\
\hline Pasman & & 39.5 & 89.4 & 5.3 & ns & -1.39 & $*$ & 100 \\
\hline Cnel. Suarez & & 35.9 & 90.7 & 2.3 & ns & -1.17 & ns & 100 \\
\hline Médanos & & 32.4 & 82.7 & 8.3 & ns & -0.80 & ns & 95 \\
\hline Algarrobo & & 37.4 & 94.4 & 5.6 & ns & -1.13 & ns & 100 \\
\hline Mean & & $30.1 \mathrm{a}$ & $84.4 \mathrm{~b}$ & & & $-1.02 b$ & & $99 a$ \\
\hline Bahía Blanca & Landraces & 42.0 & 84.0 & 10.6 & ns & -1.46 & $*$ & 99 \\
\hline Pergamino & & 29.9 & 87.7 & 11.2 & ns & -0.85 & ns & 100 \\
\hline Guatraché & & 27.1 & 72.0 & 13.9 & ns & -1.48 & $*$ & 92 \\
\hline M. Juárez & & 41.4 & 68.8 & 6.3 & ns & -1.28 & $* *$ & 98 \\
\hline Bordenave & & 31.2 & 80.5 & 13.6 & ns & -1.90 & $* *$ & 100 \\
\hline Carhué & & 29.4 & 73.3 & 2.3 & ns & -1.19 & $* *$ & 97 \\
\hline Petrovo Selo & & 16.1 & 100.0 & 0.0 & $* *$ & $-0.12^{\text {ns }}$ & - & 100 \\
\hline Senokos & & 14.2 & 95.3 & 4.6 & $*$ & -0.48 & ns & $83^{*}$ \\
\hline Mean & & $13.5 b$ & $97.4 \mathrm{a}$ & & & $-0.32 c$ & & $94 a$ \\
\hline 05L1700047 & Cultivar & 30.8 & 85.3 & 10.1 & ns & $-0.38^{\mathrm{ns}}$ & - & 100 \\
\hline 05L1700036 & & 32.4 & 57.3 & 10.1 & $*$ & -0.90 & ns & 92 \\
\hline 05L1700015 & & 30.1 & 58.7 & 12.2 & ns & -1.13 & ns & 99 \\
\hline 05L1700046 & & 36.4 & 34.7 & 12.9 & $* *$ & -0.79 & ns & 100 \\
\hline 05L1700059 & & 38.7 & 72.0 & 6.9 & ns & -0.99 & ns & 100 \\
\hline 05L1700075 & & 37.2 & 21.3 & 10.1 & $* *$ & $-0.31^{\mathrm{ns}}$ & - & 95 \\
\hline 05L1700071 & & 33.3 & 61.3 & 2.3 & $* *$ & -1.11 & ns & 100 \\
\hline 05L1700066 & & 30.1 & 32.0 & 4.0 & $* *$ & -0.64 & ns & 96 \\
\hline 05L1700032 & & 31.1 & 46.7 & 4.6 & $* *$ & -0.88 & ns & 92 \\
\hline 05L1700062 & & 21.8 & 84.0 & 16.0 & ns & -1.37 & ns & 96 \\
\hline 05L1700067 & & 32.5 & 39.3 & 4.0 & $* *$ & -0.78 & ns & 100 \\
\hline 05L1700068 & & 35.8 & 64.0 & 10.6 & ns & -1.04 & $*$ & 99 \\
\hline 05L1700070 & & 33.9 & 62.7 & 6.1 & $*$ & -1.04 & ns & 92 \\
\hline 05L1700061 & & 31.4 & 54.1 & 20.3 & ns & -1.10 & ns & 99 \\
\hline 05L1700054 & & 39.2 & 41.3 & 2.3 & $* *$ & -0.81 & ns & 99 \\
\hline Mean & & $33.0 \mathrm{a}$ & $54.3 \mathrm{c}$ & & & $-0.88 b$ & & $97 a$ \\
\hline
\end{tabular}

${ }^{1} \mathrm{PY}(\%)=\mathrm{a}^{*}$ days $+\mathrm{b}\left(\right.$ wet storage at $\left.20^{\circ} \mathrm{C} ; 38 \mathrm{~d}\right)$.

${ }^{2} P$ value among accessions when compared to ASC (Hilario Ascasubi population).

*** Significant at the 0.05 and 0.01 probability level, respectively.

For mean values, different letters $(a, b$ and $c)$ indicate significant differences $(P<0.05)$ among status. 
LSMEANS for seed biomass, initial PY and PY release traits (INFOSTAT Software; Di Rienzo et al., 2013).

\section{Results}

\section{Post-harvest PY breaking (ASC)}

No interaction was observed among storage/burial condition $\times$ time $(P>0.05)$ on PY-break dynamics during the evaluated period. A faster rate of PY loss was observed under wet storage compared to dry storage (Fig. 2A). PY break was also faster for seeds buried in the field inside permeable bags exposed to thermal and soil water content fluctuations (Fig. 2B).

PY-break dynamics under field burial conditions were adequately described by a Gompertz function (Fig. 3). $\theta_{\text {ATPY }}$ values to achieve $50 \%$ of non-PY seeds was $685^{\circ} \mathrm{Cd}$ for field burial inside permeable bags.

\section{Seed production for comparative PY experiments}

Rainfall during the 2014 growing season in EEA Hilario Ascasubi $\left(62^{\circ} 37^{\prime} \mathrm{W}, 39^{\circ} 23^{\prime} \mathrm{S}\right)$ was within the range of conditions for Argentinian $V$. villosa populations and also the Radenka II wild population (Fig. 4). Although the coldest monthly temperature and rainfall from the original sites in Petrovo Selo and Senokos for wild populations were lower and higher, respectively, than those recorded in EEA Hilario Ascasubi, such environmental conditions did not affect pod setting or seed maturation.

\section{Initial PY and dormancy release rate}

At harvest, the seed moisture content of all $V$. villosa accessions was less than $14 \%$. Seed viability was over

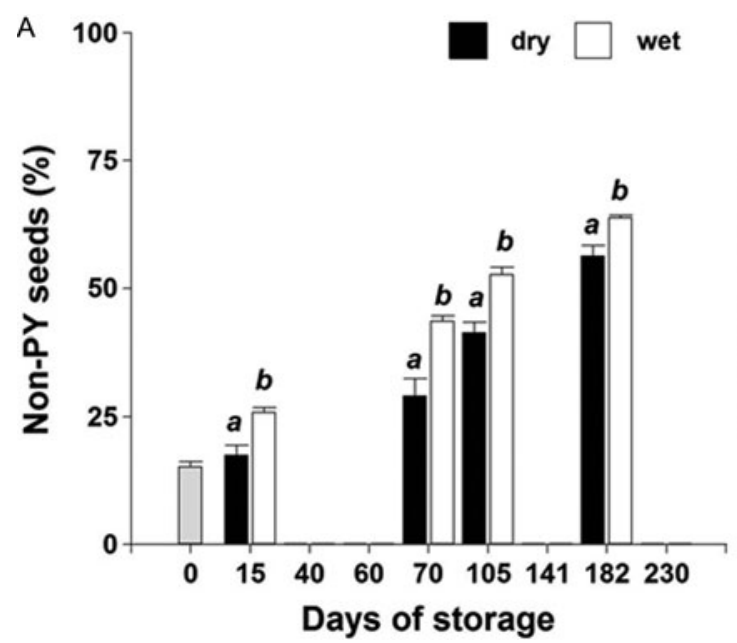

$92 \%$ in all cases. Only the wild population Senokos showed lower viability than $\operatorname{ASC}\left(F_{1,4}=18.01 ; P<\right.$ $0.01)$. The initial PY of ASC showed no statistical differences from all naturalized populations from Argentina (Table 3). Conversely, wild populations showed higher PY values than ASC, while $61 \%$ of the foreign cultivar showed lower PY figures compared to ASC (Table 3). PY-break dynamics of all populations showed a linear decrease rate under wet $/ 20^{\circ} \mathrm{C}$ storage, except for the cultivars 05L1700047 and 05L1700075, and the wild population of Petrovo Selo. The ASC PY-release rate showed no differences compared to 75 and $80 \%$ of the naturalized and improved cultivars, respectively. However, ASC showed a lower dormancy release rate compared to $81 \%$ of landraces (Table 3 ).

The initial PY was highest for wild populations, showing intermediate values in naturalized and landraces from Argentina, and the lowest percentages in breeding cultivars $\left(F_{3,134}=56.5 ; P<0.001\right)$. PY-release rates under wet storage at $20^{\circ} \mathrm{C}$ were landraces $>$ naturalized $=$ cultivar $>$ wild genotype $\left(F_{3,134}=17.8 ; \quad P<\right.$ 0.001) (Table 3).

\section{Discussion}

Our work demonstrates that humidity fluctuations during seed ageing interact with temperature to promote PY break. A similar response had been observed in other legumes (Santana et al., 2010). The interactions between PY-seed mechanisms and soil conditions determine whether, and what fraction of, the seed bank will germinate at a given time. PY-break dynamics under burial conditions in the field was adequately described by a Gompertz function (Fig. 3). This equation arises from self-regulated models where PY-release rate decreases exponentially with thermaltime after reaching the tipping point. This curve was

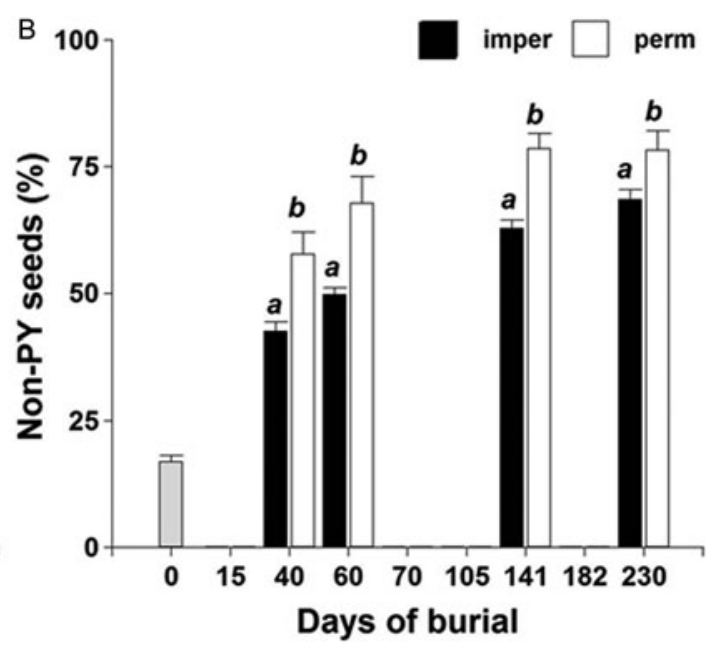

Figure 2. PY-break dynamics of the ASC Vicia villosa population under dry and wet storage at $20^{\circ} \mathrm{C}$ in the laboratory (A); or buried in the field inside permeable (perm) or impermeable (imper) bags (B). 


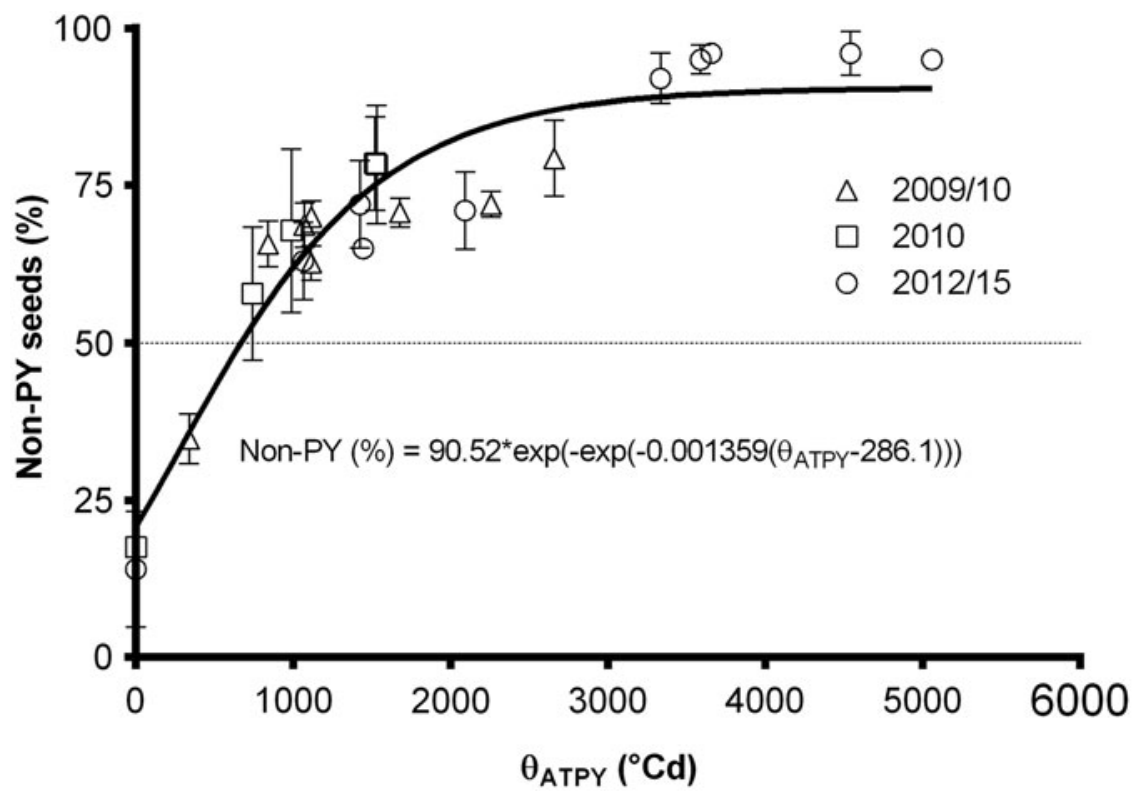

Figure 3. PY-break dynamics of Vicia villosa seeds as a function of thermal-time accumulation $\left(\theta_{A T P Y}\right)$ under conditions of field burial inside permeable bags in 2009/10, 2010 and 2012/2015.

applied successfully to describe field emergence of different legumes in Australia (Probert, 2000; van Klinken and Flack, 2005).

Water availability influenced thermal-time requirements for dormancy break in the ASC population. Seed exposure to a continuous wet storage condition, as well as a fluctuating soil moisture environment in the field, promoted PY break (Fig. 2). As reported by Jones (1928), high relative humidity promotes seedcoat breakage of $V$. villosa. The effect of humidity on PY break was also highlighted by Jayasuriya et al. (2008) and van Klinken et al. (2008). Weather and soil physical characteristics largely determine the microclimate to which seeds are exposed (Smýkal et al., 2014). This has important implications under natural conditions. According to the hypothesis of van Klinken and Goulier (2013), species with PY would have habitat-specific dormancy-release mechanisms. $V$. villosa genotypes with larger seeds might require substantially more time to imbibe prior to germination (J.L. Ekpo, pers. comm.). This adaptive disadvantage would be a trade-off for their ability to emerge from deeper soil layers. In sandy-loam soils it was observed that $V$. villosa could emerge effectively from a depth of $15 \mathrm{~cm}$ (Renzi and Cantamutto, 2013). The promoting effect of seed burial under semi-arid conditions could be related to higher moisture levels and lower temperature fluctuations (Owens et al., 1995). This could

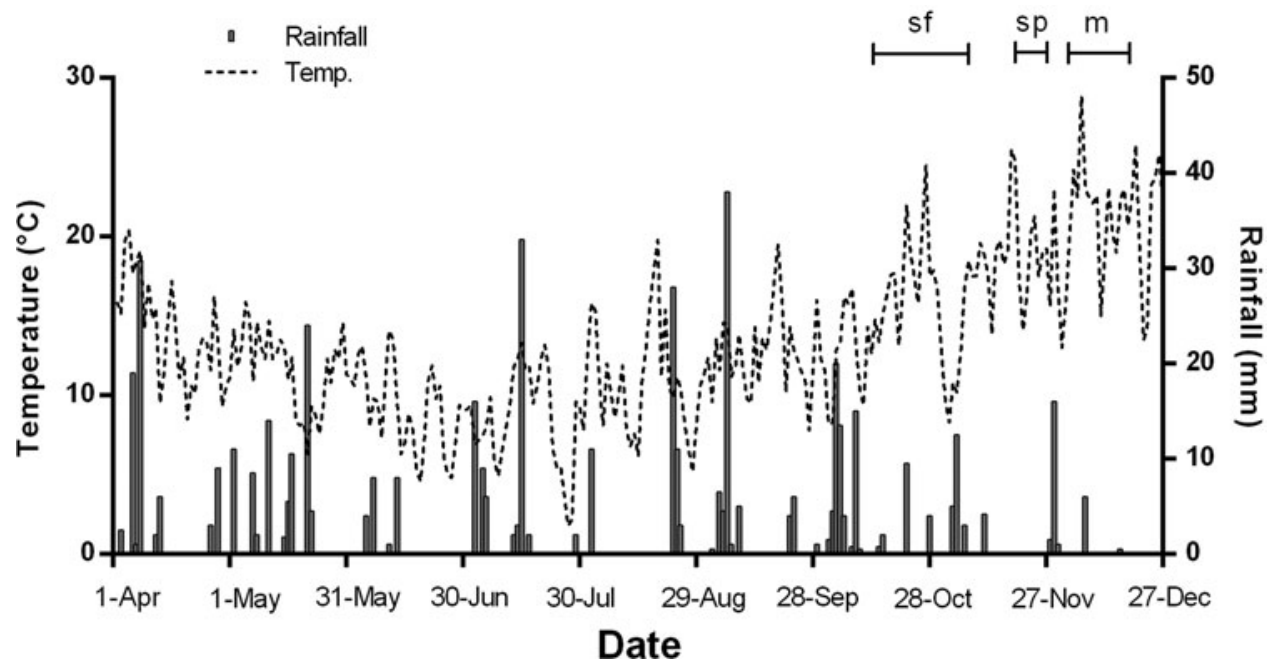

Figure 4. Mean daily temperatures and rainfall at EEA Hilario Ascasubi during the 2014 growing season. Phenological development of Vicia villosa: sf, start of flowering; sp, start of podding; m, seed maturity. 
explain why PY release occurs at a faster rate under wet field conditions, being less affected by soil temperature fluctuations. In addition, $V$. villosa has no specific light requirement for germination, hence being able to germinate from deep burial (J.L. Ekpo, pers. comm.). Thus, from an ecological perspective, it is expected that naturalized populations of $V$. villosa could establish in anthropogenic soil-disturbed areas.

Initial PY values of ASC did not differ significantly from those of other natural populations from Argentina. Thus, ASC might be useful as a model to study PY of $V$. villosa from Argentina. However, sensitivity of dormancy-release mechanisms can also differ among species (van Klinken and Goulier, 2013). Genetic differences in seeds of Trifolium subterraneum and Medicago polymorpha influenced percentages and rates of PY break (Baskin and Baskin, 2014). Similarly, Hu et al. (2009) observed contrasting PY-release patterns between two populations of Sophora alopecuroides. The rates of PY release for Argentinian genotypes under laboratory wet conditions showed significant differences compared to ASC in 25 and $82 \%$ of naturalized and landrace populations, respectively (Table 3). Moreover, $65 \%$ of the foreign accessions of $V$. villosa differed in their initial values of PY compared to ASC, but only three genotypes $(20 \%)$ differed in the rate of dormancy release (Table 3). It is probable that accession differences could be explained by genetic adaptations of $V$. villosa to the local environment (Baskin and Baskin, 2014), considering habitat-specific dormancy-release mechanisms (van Klinken and Goulier, 2013), or by selection for improved genotypes (Fuller and Allaby, 2009; Kluyver et al., 2013). Such selection traits are linked to successful early growth of planted seeds and include dormancy loss and seed size increase (Smýkal et al., 2014). More-improved genotypes, such as the cultivars, showed lower initial PY figures $(54.3 \pm 17 \%)$ compared to landraces $(82.5 \pm 9.8 \%)$, naturalized $(84.4 \pm 7.9 \%)$ and wild accessions $(97.4 \pm 2.6 \%)$ (Table 3$)$. Such a high level of PY after seed dispersal is typical of wild progenitors of cultivated legumes (Fuller and Allaby, 2009). In addition, the rate of PY release for wild types was the lowest $(0.32 \pm 0.04)$ of all studied groups. Interestingly, regression slopes were significantly different, emphasizing genotype PY differences at an intra-specific level. While naturalized populations of Argentina showed a similar initial PY compared to landraces, the rate of PY release was lower, and might be attributed to local environmental selection. This study showed that wild genotypes of $V$. villosa have a small seed weight and the response to wet$20^{\circ} \mathrm{C}$ conditions was less effective in breaking dormancy compared to naturalized, landrace or cultivar genotypes. Our results showed that wild genotypes with low seed weight might require additional environmental conditions to promote PY-loss rate. This could be related to low temperatures, which have been suggested as an effective method for breaking PY in previous studies (Dunn, 1939; cited by Baskin and Baskin, 2014).

In conclusion, results obtained in this study could be used for the development of models to predict physical dormancy changes of $V$. villosa populations, and could be applied to increase our understanding of the naturalization process and the self-regeneration capacity of such populations in fragile agroecosystems of Argentina.

\section{Acknowledgements}

The authors would like to acknowledge Dr Vojtech Holubec of the Department of Gene Bank of the Crop Research Institute (CRI) in the Czech Republic, for providing the advanced cultivars of $V$. villosa used in this study, and Dr Tomáš Vymyslický of the Research Institute for Fodder Crops, Ltd. Troubsko in the Czech Republic, for performing taxonomic identification of the Serbian accessions. We are also grateful for the important contributions of both reviewers and the Associate Editor.

\section{Financial support}

This work was supported by the Instituto Nacional de Tecnología Agropecuaria (INTA) and Agencia Nacional de Promoción Científica y Tecnológica, MINCyT (PICT-2012-2854).

\section{Conflicts of interest}

None.

\section{References}

Aarssen, L.W., Hall, I.V. and Jensen, K.I.N. (1986) The biology of Canadian weeds: Vicia angustifulia L., V. cracca L., $V$. sativa L., V. tetrasperma (L.) Schreb. and V. villosa Roth. Canadian Journal of Plant Science 66, 711-737.

Ates, S., Feindel, D., El Moneim, A. and Ryan, J. (2013) Annual forage legumes in dryland agricultural systems of the West Asia and North Africa Regions: research achievements and future perspective. Grass and Forage Science 69, 17-31.

Basaran, U., Mut, H., Onal Asci, O., Ayan, I. and Acar, Z. (2012) Germination pattern of naturally grown Lathyrus and Vicia species to different methods and seedbeds. International Journal of Plant Production 6, 325-336.

Baskin, C.C. and Baskin, J.M. (2014) Seeds: Ecology, biogeography, and evolution of dormancy and germination (2nd edition). San Diego, Academic Press. 
Baskin, J.M., Baskin, C.C. and Li, X. (2000) Taxonomy, anatomy and evolution of physical dormancy in seeds. Plant Species Biology 15, 139-152.

de Fina, A. (1992) Aptitud agroclimática de la República Argentina. Buenos Aires, Argentina, Academia Nacional de Agronomía y Veterinaria.

de Souza, T.V., Voltolini, C.H., Santos, M. and Silveira Paulilo, M.T. (2012) Water absorption and dormancybreaking requirements of physically dormant seeds of Schizolobium parahyba (Fabaceae - Caesalpinioideae). Seed Science Research 22, 169-176.

Di Rienzo, J.A., Casanoves, F., Balzarini, M.G., Gonzalez, L., Tablada, M. and Robledo, C.W. (2013) InfoStat version 2013 Grupo InfoStat, FCA. Universidad Nacional de Córdoba, Argentina. Available at http://www.infostat.com.ar (accessed 4 June 2016)

Elkins, D.M., Hoveland, C.S. and Donnelly, E.D. (1966) Germination of Vicia species and interspecific lines as affected by temperature cycles. Crop Science 6, 45-48.

Fuller, D.Q. and Allaby, R. (2009) Seed dispersal and crop domestication: shattering, germination and seasonality in evolution under cultivation. Annual Plant Reviews 38, 238-295.

Gama-Arachchige, N.S., Baskin, J.M., Geneve, R.L. and Baskin, C.C. (2011) Acquisition of physical dormancy and ontogeny of the micropyle-water-gap complex in developing seeds of Geranium carolinianum (Geraniaceae). Annals of Botany 108, 51-64.

Gama-Arachchige, N.S., Baskin, J.M., Geneve, R.L. and Baskin, C.C. (2013) Quantitative analysis of the thermal requirements for stepwise physical dormancy-break in seeds of the winter annual Geranium carolinianum (Geraniaceae). Annals of Botany 111, 849-858.

Grime, J.P., Mason, G., Curtis, A.V., Rodman, J., Band, S.R., Mowforth, M.A.G., Neal, A.M. and Shaw, S. (1981) A comparative study of germination characteristics in a local flora. Journal of Ecology 69, 1017-1059.

Gunn, C.R. (1979) Genus Vicia with notes about tribe Vicieae (Fabaceae) in Mexico and Central America. Technical Bulletin of the USDA 1601, 1-41.

Hu, X.W., Wu, Y.P. and Wang, Y.R. (2009) Different requirements for physical dormancy release in two populations of Sophora alopecuroides relation to burial depth. Ecological Research 24, 1051-1056.

Hu, X., Li, T., Wang, J., Wang, Y., Baskin, C.C. and Baskin, J.M. (2013) Seed dormancy in four Tibetan Plateau Vicia species and characterization of physiological changes in response of seeds to environmental factors. Seed Science Research 23, 133-140.

Hyde, E.O.C. (1954) The function of the hilum in some Papilionaceae in relation to the ripening of the seed and the permeability of the testa. Annals of Botany 11, 241-256.

ISTA. (2011) International rules for seed testing. Bassersdorf, Switzerland, International Seed Testing Association.

Jannink, J.L., Merrick, L.C., Liebman, M., Dyck, E.A. and Corson, S. (1997) Management and winter hardiness of hairy vetch in Maine. Technical Bulletin of the Maine Agricultural and Forest Experiment Station 167, 1-35.

Jayasuriya, K.M.G.G., Baskin, J.M. and Baskin, C.C. (2008) Cycling of sensitivity to physical dormancy-break in seeds of Ipomoea lacunosa (Convolvulaceae) and ecological significance. Annals of Botany 101, 341-352.

Jones, J.P. (1928) A physiological study of dormancy in vetch seed. Cornell University Agricultural Experimental Station Memoir 120, 1-50.
Kluyver, T.A., Charles, M., Jones, G., Rees, M. and Osborne, L.P. (2013) Did greater burial depth increase the seed size of domesticated legumes? Journal of Experimental Botany 64, 4101-4108.

Kucewicz, M., Maćkiewicz, K. and Źróbek-Sokolnik, A. (2010) Selected aspects of tiny vetch (Vicia hirsuta (L.) Gray S.F.) seed ecology: generative reproduction and effects of seed maturity and seed storage on seed germination. Acta Agrobotanica 63, 205-212.

Owens, M.K., Wallacet, R.B. and Archer, S. (1995) Seed dormancy and persistence of Acacia berlandieri and Leucaena pulverulenta in a semi-arid environment. Journal of Arid Environments 29, 15-23.

Probert, R.J. (2000) The role of temperature in the regulation of seed dormancy and germination. pp. 261-292 in Fenner, M. (Ed.) Seeds. The ecology of regeneration in plant communities (2nd edition). Wallingford, CABI Publishing.

Renzi, J.P. and Cantamutto, M.A. (2013) Vicias: Bases agronómicas para el manejo en la Región Pampeana. Buenos Aires, Argentina, Ediciones INTA.

Renzi, J.P., Chantre, G.R. and Cantamutto, M.A. (2014) Development of a thermal-time model for combinational dormancy release of hairy vetch (Vicia villosa ssp. villosa). Crop and Pasture Science 65, 470-478.

Rolston, M.P. (1978) Water impermeable seed dormancy. The Botanical Review 3, 1-32.

Samarah, N.H., Allataifeh, N., Turk, M. and Tawaha, A.R. (2003) Effect of maturity stage on germination and dormancy of fresh and air-dried seeds of bitter vetch (Vicia ervilia L.). New Zealand Journal of Agricultural Research 46, 347-354.

Samarah, N.H., Allataifeh, N., Turk, M.A. and Tawaha, M.A. (2004) Seed germination and dormancy of fresh and airdried seeds of common vetch (Vicia sativa L.) harvested at different stages maturity. Seed Science and Technology 32, 11-19.

Santana, V., Bradstock, R.A., Ooi, M., Denham, A.J., Auld, T.D. and Baeza, M. (2010) Effects of soil temperature regimes after fire on seed dormancy and germination in six Australian Fabaceae species. Australian Journal of Botany 58, 539-545.

Smýkal, P., Vernoud, V., Blair, M.W., Soukup, A. and Thompson, R.D. (2014) The role of the testa during development and in establishment of dormancy of the legume seed. Frontiers in Plant Science 351, 1-19.

Uzun, A., Sozen, E. and Acikgoz, E. (2013) Seed dormancy and germination of Vicia sativa subsp. nigra and Vicia sativa subsp. macrocarpa. Seed Science and Technology 41, 137-142.

Van Assche, J.A. and Vandelook, F. (2010) Combinational dormancy in winter annual Fabaceae. Seed Science Research 20, 237-242.

Van Assche, J.A., Debucquoy, K.L.A. and Rommens, W.A. F. (2003) Seasonal cycles in the germination capacity of buried seeds of some Leguminosae (Fabaceae). New Phytologist 153, 315-323.

van Klinken, R.D. and Flack, L. (2005) Wet heat as a mechanism for dormancy release and germination of seeds with physical dormancy. Weed Science 53, 663-669.

van Klinken, K.D. and Goulier, J.B. (2013) Habitat-specific seed dormancy-release mechanisms in four legume species. Seed Science Research 23, 181-188.

van Klinken, R.D., Lukitsch, B. and Cook, C. (2008) Interaction between seed dormancy-release mechanism, environment and seed bank strategy for a widely distributed perennial legume, Parkinsonia aculeata (Caesalpinaceae). Annals of Botany 102, 255-264. 